Tibuana

Journal of applied Industrial Engineering-University of PGRI AdiBuana

p-ISSN 2622-2027

DOI : https://doi.org/10.36456/tibuana.4.02.4005.125-130

$e$-ISSN 2622-2035

\title{
Risk Analysis Using HOR and SWOT on Spice Importers Based on Organization and Industrial Taxonomy
}

\author{
Moh. Fuad Firdaus ${ }^{1}$, Hana Catur Wahyuni ${ }^{2}$ \\ ${ }^{1,2}$ Industrial Engineering Department, Faculty of Sains and Technology \\ University of MuhammadiyahSidoarjo \\ fuadfirdaus1234@gmail.com \\ hanacatur@umsida.ac.id
}

\begin{abstract}
CV. 777 is a spice import company that has problems in mitigating events that are quite detrimental to the company. Starting from late arrival until over stock in the warehouse. The method used is the House Of Risk and SWOT methods, where with these methods the highest risk can be known and mitigation actions will be taken. This research resulted in 14 Risk Events and 27 Risk Agents where the Risk Agent with the highest ARP value will be followed up using the SWOT method. In the study, one Risk Agent with the highest ARP value or the one with the strongest influence was found, namely Risk Agent A12 with an ARP value of 255 (fluctuations in demand for goods by customers), while the Risk Agent with the weakest influence was A4 with an ARP value of 3 (imported goods). excessive) and A26 with an ARP value of 3 (miscommunication between employees). The risk agent with the highest ARP then continued using the SWOT method and resulted in four strategies, namely SO strategy, ST strategy, WO strategy, and WT strategy. With the mitigation strategy produced by the company, it will be able to minimize the risks that can occur to the company.
\end{abstract}

Keywords :About; House of Risk; Risk Analysis; Supply Chain; SWOT.

\section{INTRODUCTION}

A company that penetrates the spice and spice trading sector, with a scope of transactions both domestically and abroad. CV. 777 is a company located on Jl. Raya Nrame, No. 98, Dsn. Ivory, Ds. Wake up, district. Pungging, Kab. Mojokerto. Carrying out trading activities ranging from farmers in the country to import activities from other countries to meet domestic demand makes the company run a solid flow of transactions every day.

In the activity of buying their own goods, both local and imported, there are often delays in goods due to many factors, as a result, customers who need goods on that day also experience delays, because of that the company loses the opportunity to sell its merchandise. Not only that, warehouse stock management also experienced over capacity, causing goods to be held in containers. To minimize this possibility, it is necessary to have a risk analysis for the media so that the incident can be overcome. The method relevant to the explanation above can use the house of risk method, because this method is able to analyze the risks that will occur in an activity.

[1] Risk is called a potential loss resulting in a certain event. Risk can occur at both an individual and organizational or group scale. The source of risk itself can be from many things, ranging from planning, politics, social, and the environment. A risk analysis must continue to be monitored in order to form a fast treatment to obtain optimal results.

[2] Risk is the chance that something will happen that can affect the main goal. Risk is not certain to occur, but has the opportunity to have an impact. Every risk has consequences that can be caused, so it is important to always consider the risks that will be formed when making decisions. Therefore, there must be a deeper analysis of risk and a risk mitigation plan so that the possible risk can be reduced by the percentage of the likelihood of its occurrence.

[3]Risk categories can be divided into two forms, namely:

1. Speculative Risk

Speculative risk is a risk faced by a person, organization, or company that can provide an advantage or a loss.

\section{Pure Risk}

TiBuana, Vol. 04, No.2, 2021 | 125 
Pure risk occurs beyond the control of a person or management. One of the things that can be done to minimize the impact of pure risk is insurance.

[4] In a series of activities that exist in the company, operations are one of the things that cannot be forgotten, because the operations themselves can affect the existence and quality of the company. With good operational synergy, a comfortable social environment will be created and will have a positive impact on the company. The company must also be able to optimize the functions of operations properly so as not to create stagnation and even decline, resulting in losses for the company.

[5] The House Of Risk method is a method that can be used as an identification of risk in an activity. Starting with the framework pioneered by Laudine $\mathrm{H}$. Geraldin and $\mathrm{I}$. NyomanPujawan. Conducted a more in-depth development through two methods, namely the FMEA method and the QFD method. The House Of Risk method itself is broadly divided into 2 phases, namely the risk identification phase and risk management.

[6] In the HOR model, the severity of the risk event and the occurrence of the risk agent, which is the probable cause of the risk event, are the determinants of prioritizing the listed risk agents. The risk agent is considered to be the direct cause of one or more risk events. One risk event can be caused by more than one risk agent and one agent can cause a number of risk events. In addition, the relationship between each risk event and the risk agent is also a key figure in the model.

[7] A strategy is one step in running a company. The SWOT method is a strategic method for sorting, analyzing, and evaluating a project or business. The four factors that are used as the basis for the swot method are Strengths, Weaknesses, Opportunities, and Threasts.

[8] The SWOT method is used as a tool that acts in evaluating starting from Strengths, Weaknesses, Opportunities, and Threasts in a business management in order to obtain the maximum strategy. And then it can be applied by analyzing and sorting about everything related to these four factors.

[9] SWOT Matrix is a very useful matching tool for managers in developing types of strategies.
1. SO (Strength-Opportunity) Strategy

The internal strength of the company is the key in this strategy in seizing opportunities that exist outside the company.

2. WO (Weakness-Opportunity) Strategy

Internal weaknesses are minimized by developing external opportunities.

3. ST (Strength-Threat) Strategy

The impact of external threats in this strategy is avoided or eliminated as much as possible.

4. WT (Weakness-Threat) Strategy

Defensive strategy by reducing internal weaknesses of the company and avoiding external threats.

\section{RESEARCH METHODOLOGY}

This research itself will focus on the operational aspects that the company runs to analyze the risks that can occur and take risk mitigation actions. The data collection of this research used interviews and questionnaires with data processing which was divided into 2 steps, the first using the HOR method and the second using the SWOT method.

\section{RESULT AND DISCUSSION}

[10] The House of risk method in this study will be used as a risk identification tool to get a risk agent who has the greatest potential in causing risk. In determining the risk source to be selected, it will be based on the determination of the ARP value rating which is influenced by the severity, occurrence, and correlation of risk events and risk agents.

1. Identify risk events and risk agents. The results of this identification will be used as a questionnaire material to assess the severity and occurrence. In this study obtained 14 risk events and 27 risk agents (see table 1).

2. Assessing the level of severity and occurrence. Respondents will fill out the questionnaire given, where respondents are selected people who fill important positions in the company (see table 2).

3. Create a correlation matrix between risk events and risk agents. Where the value of 1 indicates a weak correlation, 3 is moderate correlation, and 9 is strong correlation (see table 2).

4. Calculate the ARP value with the formula $A R P_{j}=O_{j} \times \sum S_{i} R_{i j}$ (see table 2$)$.

5. Rank the ARP values from the highest to the lowest (see table 2). 
Tibuana

Journal of applied Industrial Engineering-University of PGRI AdiBuana

DOI : https://doi.org/10.36456/tibuana.4.02.4005.125-130

Table 1

Identification Risk Event and Risk Agent

\begin{tabular}{|c|c|c|c|}
\hline $\begin{array}{l}\text { Risk Event } \\
\text { Code }\end{array}$ & Risk Event & $\begin{array}{l}\text { Risk Agent } \\
\text { Code }\end{array}$ & Risk Agent \\
\hline \multirow[t]{2}{*}{ E1 } & Procurement error & A1 & $\begin{array}{l}\text { Incompatibility of the budget plan with real } \\
\text { time conditions }\end{array}$ \\
\hline & & A2 & $\begin{array}{l}\text { The presence of pests in the agricultural } \\
\text { sector }\end{array}$ \\
\hline \multirow[t]{2}{*}{ E2 } & $\begin{array}{l}\text { The occurrence of price } \\
\text { fluctuations }\end{array}$ & A3 & Crop failure on agriculture \\
\hline & & A4 & Import goods too much \\
\hline \multirow[t]{2}{*}{ E3 } & $\begin{array}{l}\text { Mismatch of the number of goods } \\
\text { from the supplier }\end{array}$ & A5 & Market monopoly \\
\hline & & A6 & Error in calculating the quantity of goods \\
\hline \multirow[t]{2}{*}{ E4 } & $\begin{array}{l}\text { Receipt of damaged goods sent by } \\
\text { the supplier }\end{array}$ & A7 & Theft in expedition \\
\hline & & A8 & Quality control supplier is not strict enough \\
\hline E5 & Availability of goods not available & $\begin{array}{l}\text { A9 } \\
\text { A10 }\end{array}$ & $\begin{array}{l}\text { Expeditions are not good at handling goods } \\
\text { Checking goods by officers who are too long }\end{array}$ \\
\hline \multirow[t]{2}{*}{ E6 } & $\begin{array}{l}\text { Mismatch between the number of } \\
\text { goods that come with the number } \\
\text { of requests from customers }\end{array}$ & A11 & Distribution delay \\
\hline & & A12 & $\begin{array}{l}\text { Fluctuations in demand for goods by } \\
\text { customers }\end{array}$ \\
\hline \multirow[t]{2}{*}{ E7 } & Slow warehouse service & A13 & Customs regulations \\
\hline & & A14 & $\begin{array}{l}\text { There are customers who reduce the quantity } \\
\text { of ordering goods }\end{array}$ \\
\hline \multirow[t]{2}{*}{ E8 } & $\begin{array}{l}\text { The capacity of goods in the } \\
\text { warehouse is over stock }\end{array}$ & A15 & New employee or in training \\
\hline & & A16 & Lack of employee expertise in their field \\
\hline \multirow[t]{2}{*}{ E9 } & $\begin{array}{l}\text { Lack of performance or operator } \\
\text { work speed }\end{array}$ & A17 & Employee fatigue \\
\hline & & A18 & Pick up of goods by the customer who is late \\
\hline \multirow[t]{2}{*}{ E10 } & $\begin{array}{l}\text { Damaged goods in warehouse } \\
\text { storage }\end{array}$ & A19 & \\
\hline & & A20 & $\begin{array}{l}\text { Error shipping goods that do not match } \\
\text { FIFO }\end{array}$ \\
\hline \multirow[t]{2}{*}{ E11 } & Goods price competition & A 21 & Market politics \\
\hline & & A22 & Late payment of receivables \\
\hline \multirow[t]{2}{*}{ E12 } & Lack of funding sources & $\mathrm{A} 23$ & There is an unexpected event \\
\hline & & A24 & $\begin{array}{l}\text { The trip was interrupted in the distribution } \\
\text { process }\end{array}$ \\
\hline \multirow[t]{2}{*}{ E13 } & Swelling of man hour & A 25 & $\begin{array}{l}\text { The process of loading goods to customers } \\
\text { that have not been completed }\end{array}$ \\
\hline & & A26 & Miscommunication between employees \\
\hline E14 & $\begin{array}{l}\text { There are complaints from } \\
\text { consumers about the number of } \\
\text { goods received does not match }\end{array}$ & A27 & Lack of accuracy \\
\hline
\end{tabular}


Tibuana

Journal of applied Industrial Engineering-University of PGRI AdiBuana

DOI : https://doi.org/10.36456/tibuana.4.02.4005.125-130

-ISSN 2622-2027

$e$-ISSN 2622-2035

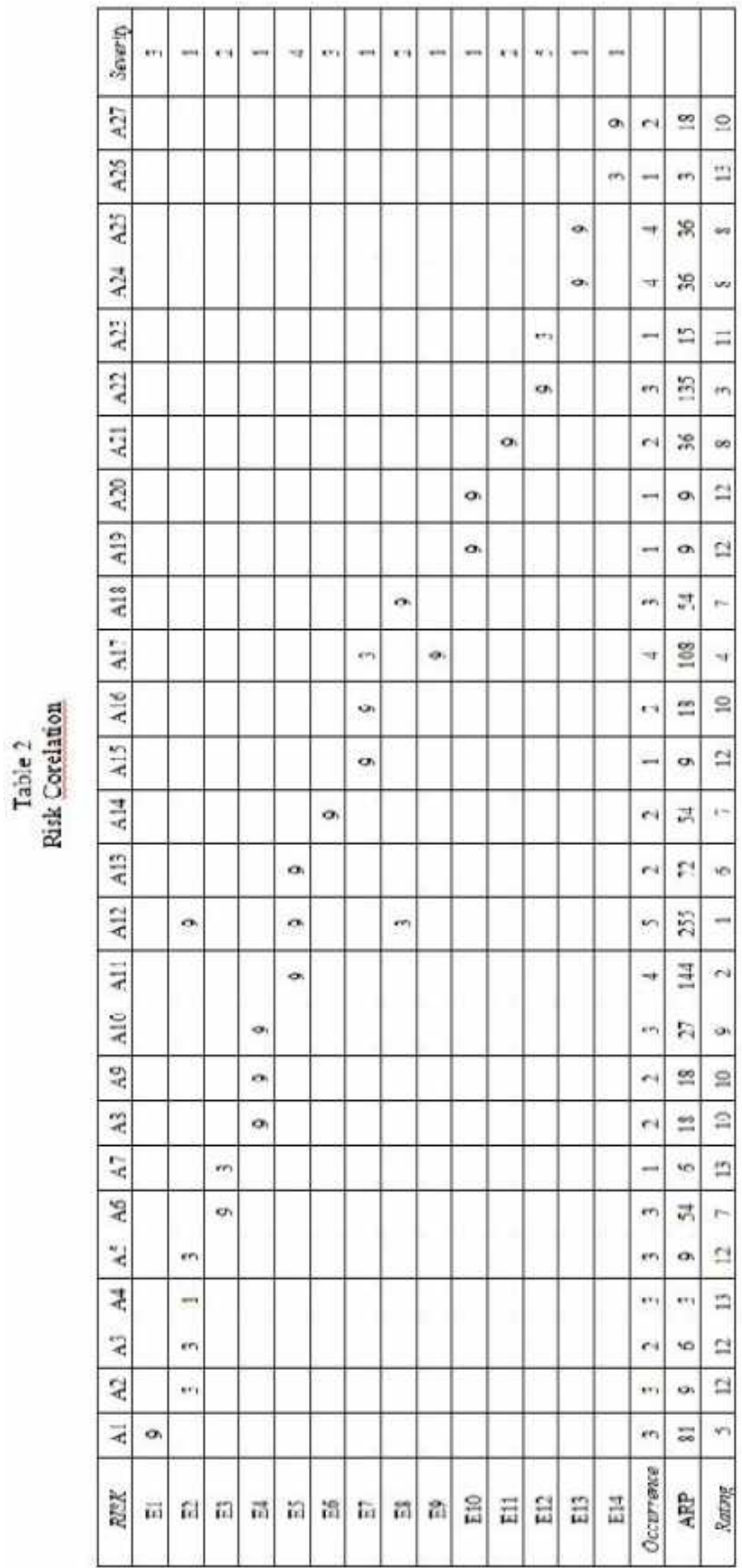

128 | TiBuana, Vol. 04, No.2, 2021 


\section{Tibuana}

Journal of applied Industrial Engineering-University of PGRI AdiBuana

DOI : https://doi.org/10.36456/tibuana.4.02.4005.125-130

Based on discussions with the management of CV. 777 it was agreed that further action would be taken by selecting the top risk agent so that prevention efforts would be more focused and optimal. Which will be used as a follow-up action, namely risk agent A12. Furthermore, handling will be carried out using the SWOT method in order to minimize the possible risks that may occur.

The method used to carry out the handling action is by using the SWOT method. By evaluating both internally and externally in the company, a maximum strategy will be designed that can be used as a mitigation measure that can be done.

1. Internal Factor Analysis

a. Strength

- The company prioritizes the best quality.

- Competitive price.

- Strategic warehouse location.

- Service friendliness.

- Speed of communication access.

b. Weaknesses

- Speed of service.

- Error in shipping quantity of goods.

- Delay in arrival of goods at the warehouse.

2. External Factor Analysis

c. Opportunity

- Set the strategy of cooperation with various parties.

- Monitor the number of requests in the market.

- Keeping up with technological advances that have developed.

- Good relationship with customers

d. Threats

- Price competition with competitors.

- An increase in the price of goods which has an impact on the quantity demanded.

- High operating costs.

- Weakening consumer purchasing power

Furthermore, the total score of each factor can be broken down, Strength 2,17, Weakness 0,65 , Opportunity 1,60, Threat 1,27 . Then it is known that the difference in the total score of the Strength and Weakness factors is $(+) 1,57$, while the difference in the total score of the Opportunity and Threat factors is $(+) 0,5$.

From SWOT method the company is in the growth quadrant where the quadrant shows a very favorable situation for the company, because the company has opportunities and strengths. The strategy that must be applied in this condition is to support an aggressive growth policy so that the company can maximize its capabilities and take advantage of all existing opportunities.

1. SO Strategy

- Cooperating with various business actors to create market expansion.

- Adjusting consumer needs and consumerpurchasing power.

-Maintain good relationship with consumers.

2. WO Strategy

- Improve the quality of service.

- Minimize errors that can harm customers.

3. ST strategy

- Conduct crosschecks both on the market and with suppliers on a regular basis.

- It is best to get competitive prices from suppliers.

4. WT Strategy

- Expanding supplier relations to obtain the best alternative.

\section{CONCLUSION}

1. Risk factors based on organizational aspects and industry taxonomy with the highest five ARP scores include:First, the fluctuation of goods by customers. With risk code A12 and ARP value of 255. Second, delay in distribution. With risk code A11 and ARP value of 144. Third, late receivables. With risk code A22 and ARP value of 135. Fourth, employee fatigue. With the risk code A17 and the ARP value of 108. Fifth, the incompatibility of the budget draft with real time conditions. With risk code A1 and ARP value of 255 .

2. The most powerful and influential risk factor analyzed by the HOR method is the fluctuation in demand for goods by customers with the risk agent code A12 which obtains an ARP value of 255. And this risk factor will later be taken for further action to be taken to handle efforts and get the expected results . 
Tibuana

Journal of applied Industrial Engineering-University of PGRI AdiBuana

p-ISSN 2622-2027

$e$-ISSN 2622-2035

DOI : https://doi.org/10.36456/tibuana.4.02.4005.125-130

BerkatAbadi Di Balikpapan', Agora, Vol. 5, No. 3, Hal. 1-5, Universitas Kristen Petra. mitigation actions obtained from the SWOT method, namely:

\section{a. SO Strategy}

First, to collaborate with various business actors in order to create market expansion. Second, adjust consumer needs and consumer purchasing power. Third, maintain good relations with consumers. b. WO Strategy

First, improve the quality of service. And secondly, minimizing errors that can harm customers.

c. ST strategy

First, cross-check both the market and suppliers on a regular basis. Second, it is best to get competitive prices from suppliers.

d. WT Strategy

By expanding supplier relations in order to obtain the best alternative.

\section{REFERENCES}

[1] Fasa, Muhammad Iqbal, 2016, 'ManajemenRisikoPerbankanSyariah Di Indonesia', JurnalStudiEkonomi Dan Bisnis Islam, Vol. I, Nomor. 2, Hal. 36-53, UIN SunanKalijaga Yogyakarta.

[2] Hazmi, Farah Widyan, Karningsih, Putu Dana, Supriyanto, Hari, 2012, 'Penerapan Lean Manufacturing UntukMereduksi Waste Di PT Arisu', JurnalTeknik ITS, Vol. 1, No. 1, Hal. 135-140, InstitutTeknologiSepuluhNopember.

[3] Vikaliana, Resista, 2017, 'FaktorFaktorRisikoRisikoDalam

Perusahaan JasaPengiriman', JurnalLogistik Indonesia, Vol. 01, No. 01, Hal. 68-76, InstitutIlmuSosial Dan Manajemen STIAMI.

[4] Zulkarnaen, Kezia, 2017, 'AnalisisFungsiOperasionalPada CV.

[5] Kristanto, BayuRizki, Hariastuti, Ni LuhPutu, 2014, 'Aplikasi Model House Of Risk (Hor) UntukMitigasiRisikoPada Supply Chain Bahan Baku Kulit', JurnalImiahTeknikIndustri, Vol. 13, No. 2, Hal. 149-157, InstitutTeknologiAdhi Tama Surabaya.

[6] Ma, Hoi-Lam, Wong, Wai-Hung Collin, 2018, 'A Fuzzy-Based House Of Risk Assessment Method For Manufacturers In Global Supply Chains', Emerald Insight, Hal. 1-14, Hang Seng Management College.

[7] Cahyono, Puguh, 2016, 'ImplementasiStrategiPemasaranDen ganMenggunakanMetodeSwotDalam UpayaMeningkatkanPenjualanProdu kJasaAsuransiKecelakaan Dan KematianPada PT. Prudential CabangLamongan', JurnalPenelitianIlmuManajemen, Volume. 1, No. 02, Hal. 130-138, Universitas Islam Lamongan.

[8] Büyüközkan, Gülçin, Ilıcak, Öykü, 2018, 'Integrated SWOT Analysis With Multiple Preference Relations Selection Of Strategic Factors For Social Media', Emerald Insight, Galatasaray University.

[9] Saputra, Andreas Dwi, 2015, 'AnalisaStrategiBersaingPada CV. Eka Jaya', Agora, Vol. 3, No. 1, Hal. 569-578, Universitas Kristen Petra.

[10] Winarso, Kukuh, Jufriyanto, Moh, 2020, 'Rework Reduction And Quality Cost Analysis Of Furniture Production Processes Using The House Of Risk (HOR)', IOP Publishing, Hal. 1-10, University Of Trunjoyo Madura. 